\title{
PERLINDUNGAN MASYARAKAT PIDIE DARI COVID-19 MELALUI PEMAKAIAN MASKER
}

DOI: https://doi.org/10.33024/jkpm.v4i4.3966

\author{
Lisa Rahmi ${ }^{1}$, Cut Raihanah ${ }^{2 *}$, Miniharianti ${ }^{3}$, Tuti Sahara ${ }^{4}$, Isni Hijriana ${ }^{5}$, \\ Yusnita ${ }^{6}$
}

Disubmit: 07 Maret 2021 Diterima: 07 April 2021 Diterbitkan: 03 Agustus 2021

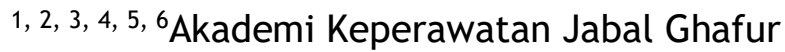

Email Korespondensi : cutraihanah@gmail.com

\begin{abstract}
ABSTRAK
Virus corona (COVID-19) dapat menyebar melalui percakapan dan pernapasan normal dengan orang yang terpapar. Salah satu cara untuk mencegah terjadinya penularan COVID-19 adalah melalui pemakaian masker. Hal ini sejalan dengan imbauan Pemerintah untuk menerapkan protokol kesehatan pencegahan COVID19, salah satunya melalui pemakaian masker kain untuk masyarakat umum. Tujuan pengabdian masyarakat ini adalah meningkatkan kesadaran masyarakat Pidie untuk menggunakan masker kain ketika melakukan aktivitas di luar rumah sebagai pencegahan penyebaran COVID-19 serta memberikan penjelasan mengenai cara menggunakan masker kain yang benar di saat melakukan aktivitas di luar rumah selama masa pandemi COVID-19. Kegiatan ini berlangsung pada tanggal 22 April 2020 di Simpang 4 Kota Sigli dengan cara membagikan masker kain kepada masyarakat Pidie yang beraktivitas di luar rumah disertai dengan sosialisasi tentang cara pemakaian masker kain yang benar. Antusias masyarakat Pidie dalam menerima edukasi dan pembagian masker kain terlihat selama kegiatan ini. Diharapkan kesadaran masyarakat Pidie untuk selalu menggunakan masker kain ketika beraktivitas di luar rumah semakin meningkat sehingga dapat menurunnya resiko penyebaran COVID-19 di lingkungan masyarakat Pidie yang harus tetap beraktivitas di luar rumah.
\end{abstract}

Kata Kunci : Pencegahan, COVID-19, Pemakaian Masker, Masyarakat Pidie

\begin{abstract}
The corona virus (COVID-19) can be spread through interacting and normal breathing with exposed people. One of the way to prevent the transmission of COVID-19 is through wearing masks. This is in line with the government's appeal to implement health protocols for the prevention of COVID-19, one of which is through wearing cloth masks for the general public. The aim of this community service is to increase the awareness of the Pidie community to use cloth masks when carrying out activities outside the home as a prevention of the spread of COVID-19 and to provide an explanation of how to use the correct cloth masks when doing activities outside the home during the COVID-19 pandemic. This activity took place on April 22, 2020 at Simpang 4, Sigli City by distributing cloth masks to Pidie people who had activities outside the home accompanied by socialization on how to use cloth masks correctly. The enthusiasm of the Pidie
\end{abstract}


community in receiving education and distributing cloth masks was seen during this activity. It is hoped that the awareness of the Pidie community to always use cloth masks when doing activities outside the home will increase so that it can reduce the risk of spreading COVID-19 in the Pidie community who have to continue their activities outside the home.

Keywords: Prevention, COVID-19, Use of Masks, Pidie Society

\section{PENDAHULUAN}

Coronavirus adalah suatu kelompok virus yang dapat menyebabkan penyakit pada hewan atau manusia. Beberapa jenis coronavirus diketahui menyebabkan infeksi saluran nafas pada manusia mulai dari batuk pilek hingga yang lebih serius seperti Middle East Respiratory Syndrome (MERS) dan Severe Acute Respiratory Syndrome (SARS). Coronavirus jenis baru yang ditemukan menyebabkan penyakit menular yang disebut COVID-19. Virus baru dan penyakit yang disebabkannya ini tidak dikenal sebelum mulainya wabah di Wuhan, Tiongkok, bulan Desember 2019. COVID-19 ini sekarang menjadi sebuah pandemi yang terjadi di banyak negara di seluruh dunia, termasuk Indonesia (WHO, 2020). Di Indonesia, kasus pertama COVID-19 diumumkan pada tanggal 2 Maret 2020 (Syapitri et al., 2020). Sementara di Kabupaten Pidie data kasus COVID-19 per tanggal 9 April 2020 menurut informasi dari Tim Gugus Tugas Percepatan Penanganan Covid-19 Kabupaten Pidie yaitu jumlah orang dalam pemantauan (ODP) sebanyak 22 orang dengan rincian 12 orang dalam pemantauan, yang sudah selesai proses pemantauan 10 orang. Sedangkan jumlah pasien dalam pengawasan (PDP) 9 orang, dengan rincian 1 PDP yang dirawat di Rumah Sakit Umum (RSU) Tgk Chik Ditiro, Sigli, 5 orang disisolasi di rumah, dan tiga orang lainnya sudah pulang (Salman, 2020).

Virus corona dapat menyebar melalui percakapan dan pernapasan normal dengan orang yang terpapar. Meskipun angka kematian akibat COVID-19 tergolong rendah yaitu sekitar 2-3\%, akan tetapi tindakan pencegahan tetap perlu dilakukan yaitu dengan membiasakan diri untuk menggunakan pembersih tangan yang mengandung alkohol atau mencuci tangan dengan menggunakan air dan sabun serta dengan memakai masker (Fernalia et al., 2021). Pemakaian masker diperlukan bagi setiap orang agar tidak saling menulari virus corona. Ada kesempatan tinggi penularan terjadi ketika orang sakit berinteraksi dengan orang sehat dan orang sehat berinteraksi dengan yang lain juga. Penelitian terbaru menunjukkan batuk dan bersin dapat membuat percikan liur terlontar lebih jauh daripada yang diperkirakan sebelumnya. Penggunaan masker diharuskan juga terkait dengan percikan liur atau droplet (Damhuri, 2020) dikarenakan potensi penyebaran COVID-19 menjadi semakin besar apabila sudah mencapai tingkat komunitas dimana seseorang dapat terinfeksi tanpa sadar kapan dan dimana hal itu terjadi (Fasya et al., 2021).

Masker yang digunakan perlu menyesuaikan dengan tingkat intensitas kegiatan tertentu, termasuk untuk menghadapi merebaknya wabah virus corona COVID-19 sekarang ini (Ashar, 2020). Ada tiga jenis masker yang dapat digunakan selama masa pandemi virus corona (Maharani, 2020), salah satunya masker kain. Masker kain dapat dipakai maksimal hanya 4 jam dan harus ganti dengan masker baru dan bersih. Apabila masker yang dipakai basah atau lembab harus segera diganti. 
Masyarakat disarankan membawa beberapa masker untuk beraktivitas, penggunaan masker pun harus tepat seperti menutup hidung dan mulut. Cara melepas masker cukup dengan menarik bagian tali dan langsung disimpan ke kantong kertas atau plastik tertutup guna mencegah penyebaran virus ke barang di sekitarnya (Rokom, 2020). Masker kain dapat digunakan untuk mencegah penularan sekaligus mengantisipasi kelangkaan masker yang terjadi di pasar seperti apotek dan toko-toko kesehatan (Ashar, 2020).

Sebagaimana imbauan Pemerintah untuk menerapkan protokol kesehatan pencegahan COVID-19, salah satunya melalui pemakaian masker kain untuk masyarakat umum, kami tertarik melakukan pengabdian kepada masyarakat dengan membagikan masker kain dan kepada masyarakat Pidie yang beraktivitas di luar rumah disertai dengan sosialisasi tentang cara pemakaian masker kain yang benar untuk meminimalisasi meningkatnya penularan COVID-19 di Kabupaten Pidie. Pemberian edukasi melalui sosialisasi atau penyuluhan dapat menjadi salah satu upaya yang dapat dilakukan untuk menekan kasus dan mencegah penularan COVID-19 (Agustin et al., 2021).

\section{MASALAH}

Meskipun sudah terdapat kasus COVID-19 di Kabupaten Pidie, akan tetapi Pemerintah Daerah belum memutuskan untuk menerapkan aturan Pembatasan Sosial Berskala Besar (PSBB) di Kabupaten Pidie sehingga banyak masyarakat yang masih melakukan aktivitas di luar rumah untuk memenuhi kebutuhan sehari-hari, terutama di daerah perkotaan (Kota Sigli). Padahal saat situasi seperti ini, penerapan protokol kesehatan sangat dibutuhkan untuk mencegah penyebaran virus COVID-19, salah satunya dengan penggunaan masker kain bagi masyarakat yang melakukan aktivitas di luar rumah.

Tim kami memilih lokasi Simpang 4 Kota Sigli, Kabupaten Pidie sebagai tempat pengabdian masyarakat dikarenakan lokasi ini banyak dilalui oleh masyarakat Kabupaten Pidie.

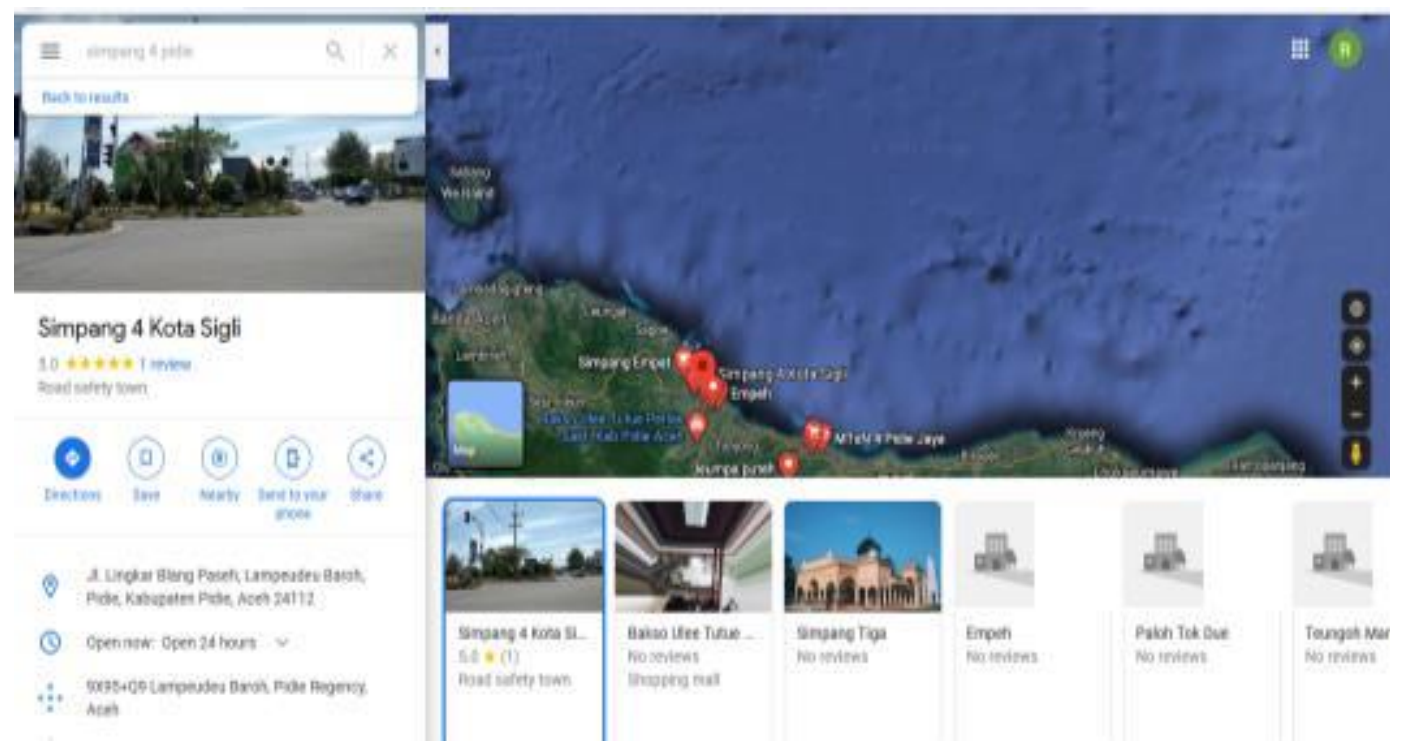

Gambar 2.1 Peta Lokasi Kegiatan Pengabdian Kepada Masyarakat 


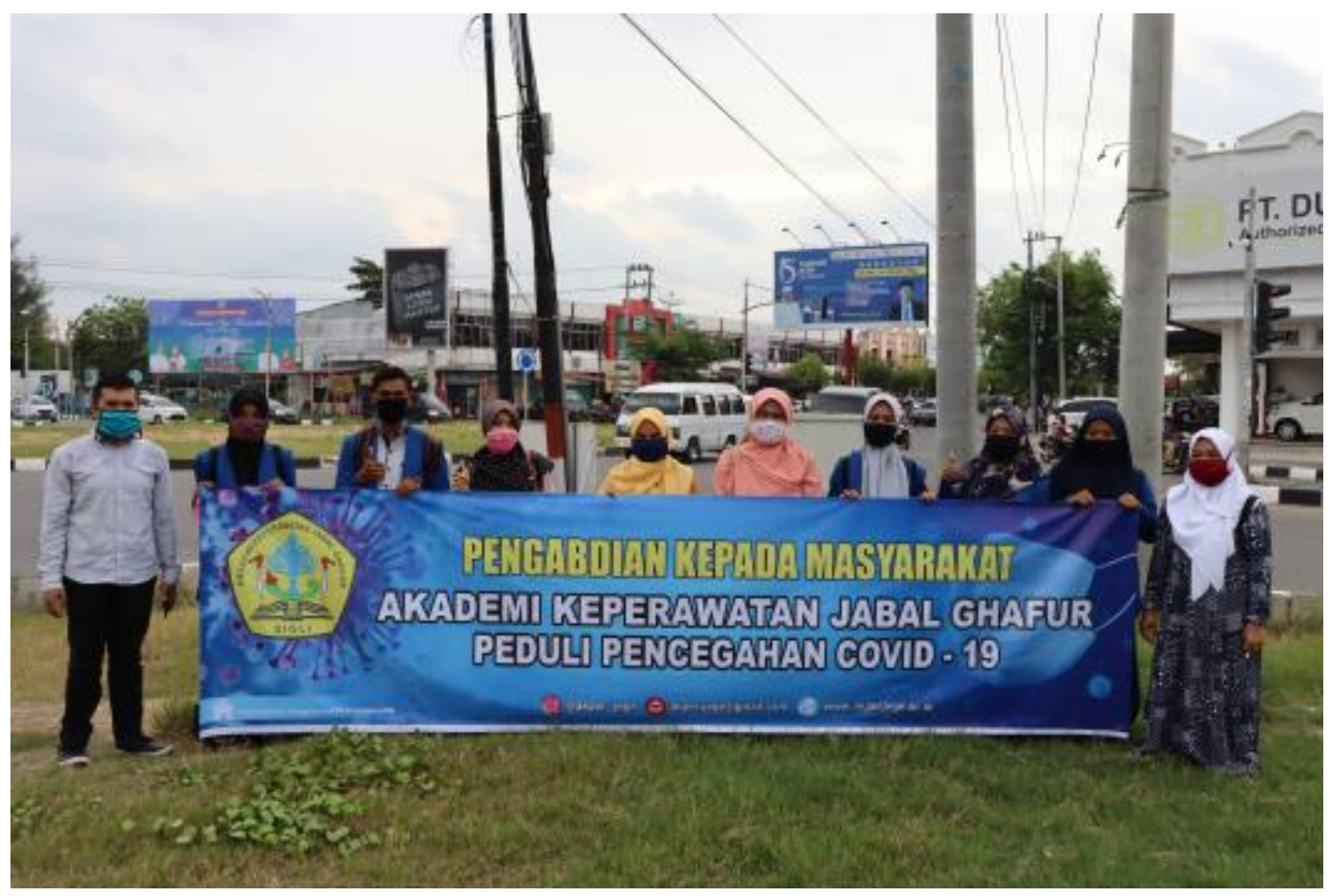

Gambar 2.2

\section{Lokasi Kegiatan Pengabdian Kepada Masyarakat}

\section{METODE}

1. Tujuan Persiapan

Pada tahap ini dilakukan persiapan/pengumpulan masker kain melalui campaign donasi masker, penentuan titik lokasi, dan pengurusan perizinan.

2. Tahap Pelaksanaan

Kegiatan ini dilakukan dengan membagikan masker kain kepada masyarakat Pidie yang beraktivitas di luar rumah disertai dengan sosialisasi tentang cara pemakaian masker kain yang benar. Kegiatan berlangsung pada tanggal 22 April 2020 di Simpang 4 Kota Sigli.

3. Evaluasi
a. Struktur Sasaran kegiatan pengabdian ini adalah masyarakat Kota Sigli,
Kabupaten Pidie yang melewati lokasi Simpang 4 Kota Sigli.

\section{b. Proses}
Pelaksanaan kegiatan dilakukan pada hari Rabu, 22 April 2020 pukul 14.00 s.d. 17.00 WIB. 


\section{HASIL DAN PEMBAHASAN}

Hasil yang dicapai dalam pengabdian ini adalah memberikan edukasi dan pendampingan dalam meningkatkan kesadaran masyarakat Pidie untuk menggunakan masker kain ketika melakukan aktivitas di luar rumah sebagai pencegahan penyebaran COVID-19. Selain itu, melalui kegiatan pengabdian ini, masyarakat sasaran mendapatkan penjelasan mengenai cara menggunakan masker kain yang benar di saat melakukan aktivitas di luar rumah selama masa pandemi COVID-19.

Adapun luaran yang dihasilkan dari kegiatan pengabdian ini adalah menurunnya resiko penyebaran COVID-19 di lingkungan masyarakat Pidie yang harus tetap beraktivitas di luar rumah.
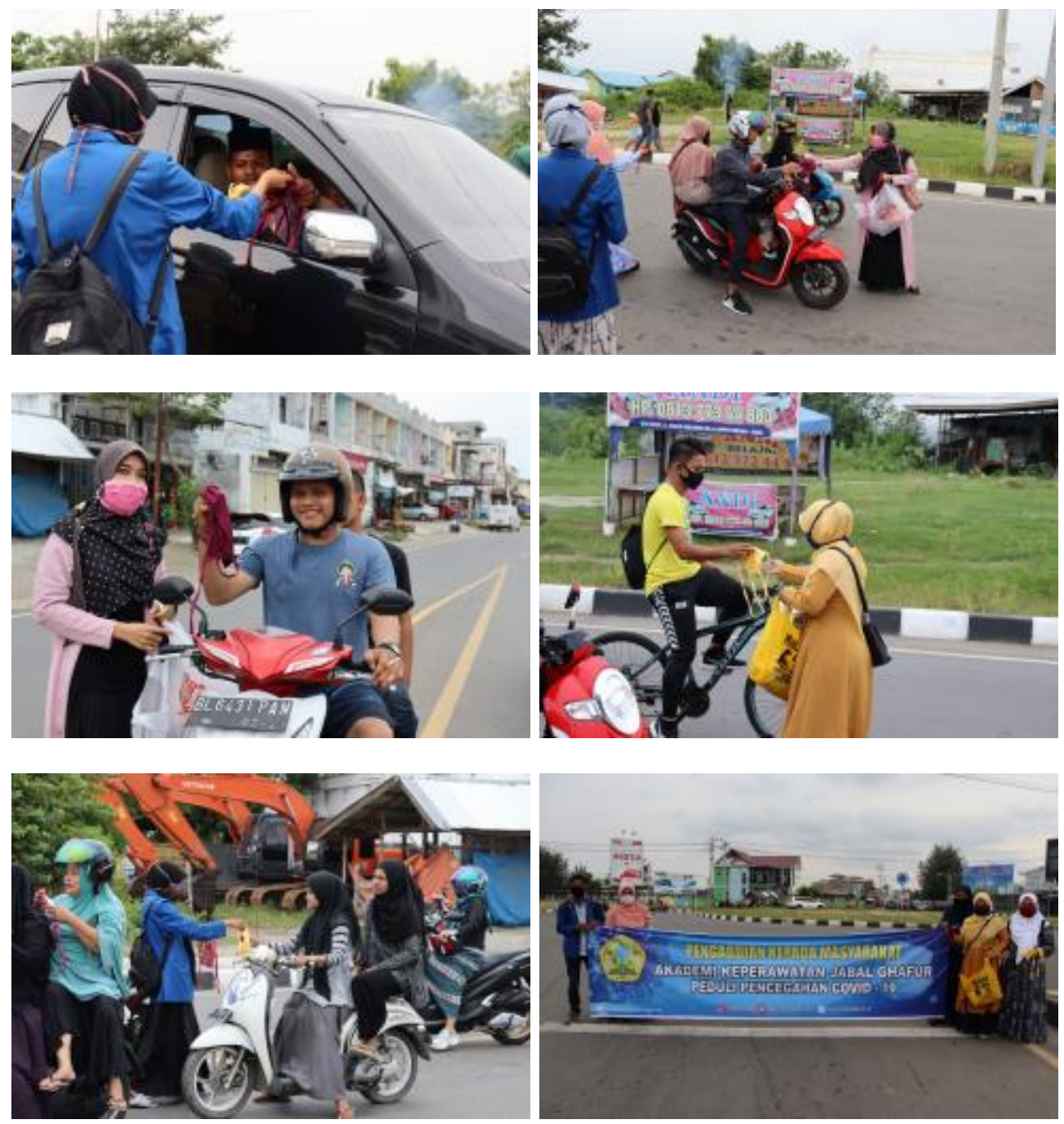

Gambar 4.1 Foto Kegiatan Pengabdian Kepada Masyarakat 


\section{KESIMPULAN}

Kegiatan pengabdian yang sudah dilakukan berupa pembagian masker kain kepada masyarakat Pidie yang beraktivitas di luar rumah disertai dengan sosialisasi tentang cara pemakaian masker kain yang benar. Diharapkan dengan kegiatan pengabdian ini dapat meningkatkan kesadaran masyarakat Pidie untuk selalu menggunakan masker kain ketika beraktivitas di luar rumah guna mencegah peningkatan penyebaran COVID-19 khususnya di Pidie.

\section{DAFTAR PUSTAKA}

Agustin, F., Restuni, F. R., Detty, A. U., Hutasuhut, A. F., Artini, I., \& Dalfian, D. (2021). Penyuluhan Tentang Pentingnya Mematuhi Protokol Kesehatan di Era Pandemi COVID-19 di UPT Puskesmas Kampung Sawah Bandar Lampung. Jurnal Kreativitas Pengabdian Kepada Masyarakat (PKM), 4(1), 207-212.

Ashar, S. (2020). Yuk mengenal jenis masker yang pas untuk kita pakai melawan virus corona. PT. Kontan Grahanusa Mediatama. https://kesehatan.kontan.co.id/news/yuk-mengenal-jenis-masker-yangpas-untuk-kita-pakai-melawan-virus-corona.

Damhuri, E. (2020). Bagaimana Virus Corona Menyebar dan Menular ke Orang Lain? I Republika Online. https://www.republika.co.id/berita/q8afvp440/bagaimana-viruscorona-menyebar-dan-menular-ke-orang-lain.

Fasya, H., Pratama, S. A., Mandala, Z., \& Pebrian, U. (2021). Penyuluhan Tentang Protokol Kesehatan Covid -19 Pada Masyarakat Di Puskesmas Sumur Batu Teluk Utara Bandar Lampung. Jurnal Kreativitas Pengabdian Kepada Masyarakat (PKM), 4(1), 195-199.

Fernalia, F., Pawiliyah, P., Rahmawati, I., Juksen, L., Sanisahhuri, S., \& Rizal, S. (2021). Sosialisasi Pengunaan Masker Dan Pembagian Masker Kepada Warga Untuk Pencegahan Covid 19 Di Pasar Tradisional Kota Bengkulu. Jurnal Kreativitas Pengabdian Kepada Masyarakat (PKM), 4(1), 10-17.

Maharani, T. (2020). Masyarakat Disarankan Gunakan Masker Kain Saat Berada di Tempat Umum. https: / / nasional.kompas.com/read/2020/04/04/17185461/masyarakatdisarankan-gunakan-masker-kain-saat-berada-di-tempat-umum.

Rokom. (2020). Begini Aturan Pemakaian Masker Kain yang Benar. Sehat Negeriku. $\quad$ https://sehatnegeriku.kemkes.go.id/baca/rilismedia/20200609/5834051/begini-aturan-pemakaian-masker-kainbenar/.

Salman. (2020). Hasil Rapid Test, Satu PDP di Pidie Positif Corona. https://www.ajnn.net/news/hasil-rapid-test-satu-pdp-di-pidie-positifcorona/index.html.

Syapitri, H., Siregar, L. M., \& Saragih, F. L. (2020). Pencegahan Penularan Covid19 Melalui Sosialisasi Dan Pembagian Masker Di Pasar Pringgan Medan. Jurnal Kreativitas Pengabdian Kepada Masyarakat (PKM), 3(2), 422-429.

WHO. (2020). Pertanyaan jawaban terkait COVID-19 untuk publik. https://www. who.int/indonesia/news/novel-coronavirus/qa/qa-forpublic. 